\title{
Research \\ Selling Conservation? Scientific Legitimacy and the Commodification of Conservation Tourism
}

\author{
$\underline{\text { Jenny A. Cousins }}^{1}, \underline{\text { James Evans }}^{1}$, and $\underline{\text { Jon Sadler }}^{2}$
}

\begin{abstract}
Conservation tourism is a rapidly growing subsector of ecotourism that engages paying volunteers as active participants in conservation projects. Once the preserve of charities, the sector now hosts a proliferation of private companies seeking to make money by selling international conservation work to tourists as a commodity. The commodification of conservation depends upon balancing the scientific legitimacy of projects against the need to offer desirable tourist experiences. Drawing on interviews with UK tour operators and their counterparts in South Africa who run the conservation projects, we explore the transnational geography of commercial conservation tourism, charting how scientific legitimacy is constructed and negotiated within the industry. Although conservation tourism makes trade-offs between scientific rigor and neoliberal market logic, it is a partial and plural process that resists simple categorization. We conclude by considering the difference that commodification makes to conservation science, and vice versa.
\end{abstract}

Key Words: commodification; conservation science; conservation tourism; scientific legitimacy; South Africa; United Kingdom

\section{INTRODUCTION}

The explosive growth of ecotourism over the last decade has demonstrated the scale of demand for holidays that promise to make a positive impact on the environment (Blamey 2001, Weaver 2001). As growing public environmental concern collides with a culture of increasing mobility among the richer inhabitants of the planet, different types of ecotourism are emerging to meet this demand. Of these, conservation tourism is arguably the fastestgrowing sector (Mumby et al. 1995, Russel 1995, Weiler and Richins 1995, Turner et al. 2001, McGehee 2002, McGehee and Norman 2002, Broad 2003, Halpenny and Caissie 2003, Galley and Clifton 2004, Coghlan 2008). Conservation tourism is a fusion of ecotourism and volunteer tourism, whereby visitors pay to work as participants on conservation projects (Cousins 2007). Volunteer tourism is one of the major growth areas of alternative tourism and is a direct interactive experience in which individuals "volunteer in an organized way to undertake holidays that might involve aiding or alleviating the material poverty of some groups in society, the restoration of certain environments or research into aspects of society or environment" (Wearing 2001: 1). According to Wearing (2001), volunteer tourists are seeking a tourist experience that is mutually beneficial; one that will not only contribute to their personal development but also positively and directly to the social, natural, or economic environments in which they participate. Often these experiences cross the boundaries between work and leisure (Stebbins and Graham 2004). For example, individuals may volunteer in order to gain work experience and as a novel holiday.

Like ecotourism, this model of conservation is touted as a potential win-win-win scenario for local people, conservation, and Western tourists or tourism operators. The importance of getting people involved in conservation is enshrined in Article 13 of the Convention on Biodiversity (Secretariat of the Convention on Biological Diversity 2001), and no less an advocate of biodiversity than Edward Wilson (1992) has identified ecotourism and its variants as essential ingredients of effective global conservation. Conservation tourism can also be viewed as part of the growing demand from Western 
tourists for more proactive and emotive experiences that go beyond Urry's (1990) classic "tourist gaze," where they can engage with nature in a more meaningful way. Existing studies provide a diversity of reasons why people choose to participate, including: an interest in conservation, a desire to "make a difference," personal development, career development, a desire to meet like-minded people, a passion for specific animals and places, having fun, and traveling to new destinations (Caissie and Halpenny 2003, Weston et al. 2003, Galley and Clifton 2004, Broad 2003, Campbell and Smith 2006, Lorimer 2009). Some may be "ego-tourists," merely seeking such experiences for the status that comes with them (Wheeller 1993).

Conservation volunteers can be split into four main groups or markets: the general public, gap year, university students or recent graduates, and sixthform students (Cousins 2007). In 2005, approximately 7550 people went on conservation holidays with UK organizations alone (Cousins 2007). Although the first conservation tourism holidays were offered by charities such as Earthwatch Institute and British Trust for Conservation Volunteers (BTCV), these organizations now make up only a small part of the sector. Since 1995, a number of private companies have been formed to exploit the growing demand for this type of holiday, both in the United Kingdom and abroad. Within the wider context of environmental governance, conservation tourism extends freemarket environmentalism into the conservation sector. The appeal to cash-strapped and resourcepoor governments and non-governmental organizations (NGOs) of using the free market to organize conservation (especially as pressure for data increases due to international environmental agreements (Bell et al. 2008)), added to the massive growth of international tourism, means that conservation tourism is becoming a serious driver of conservation.

Conservation tourists pay for the promise of "doing" conservation, rather than simply knowing that the cost of their holiday will be used to support conservation. Operators in the United Kingdom source and market conservation projects, which are usually privately run and often occur on privately owned land. Although previous work has highlighted the commodification of nature in its different forms (Castree 2003) and the problems associated with extending science beyond its traditional contexts (Demeritt 2000), less attention has been paid to the way in which actual scientific practice becomes commodified as part of this process. For example, organizations that provide conservation projects are not simply conservationists but capitalists seeking to generate profits, and the volunteers are simultaneously conservationists and customers.

Our focus is on the genesis and operation of private companies as they represent the main source of growth in the sector and constitute a new form of conservation governance. We trace the relations between companies in the United Kingdom and conservation projects overseas, paying special attention to the way in which scientific legitimacy is constructed and commodified. The first section of the paper considers the dual status of conservation as a science and an ethic, and sets the study within the literature concerning the commodification of nature and conservation governance. We then outline the scope and methodological approach of the study, before addressing the substantive aims of the paper. First, how are conservation experiences commodified? Second, how are relations formed between UK operators and conservation projects? Third, how is scientific legitimacy constructed and regulated within conservation tourism networks? We conclude by discussing the potential implications of the commodification of conservation science.

\section{Conservation Tourism and the Commodification of Nature}

Nature conservation has always presented an intriguing mixture of science and personal beliefs, which relates values to objective inquiry in an almost unique way. As the UK Parliamentary Office for Science and Technology (POST) report entitled "Biodiversity and Conservation" notes: "... the range of people's values for nature mean that some organisms, habitats and landscapes are more highly valued than others... while value judgments cannot be described as 'scientific', scientific methods can be used to defend conservation value" (POST 2000: 4). The dual character of nature conservation can be traced back to its origins in the popular naturalist movements of the 19th and 20th Centuries and its subsequent marriage to the formal science of ecology as governments responded to the need to manage their natural heritage. As a result, "conservation discourses are imbricated with the 
practices, mind-sets and narratives of the science of ecology" (Adams 1997: 280) and, one might add, vice versa.

The dual character of conservation is critical in understanding its appeal as a form of tourism. Conservation tourists value nature on a personal level and are generally committed to conservation to a greater or lesser degree. The scientific methods of conservation allow this moral commitment to be put into practice, whereas the personal values attached to nature make conservation science emotionally charged (Whatmore 2002, Lorimer 2007; J. Cousins, J. P. Sadler, and J. Evans, "I've paid to observe lions, not map roads!"- the emotional economy of conservation tourism in South Africa, unpublished manuscript). It is this dual appeal of conservation tourism that makes it a highly marketable product, as it combines emotional reward with the moral achievement of making a difference.

A growing proportion of the conservation tourism sector occurs in a "marketized" environment as a form of economic exchange. The shift from NGOs, like Earthwatch, which ran the first forms of conservation tourism, toward commercial tour operators is transforming the sector into a fullfledged industry. The role of NGOs in environmental governance is fairly well understood: they extend relations beyond the state, they tend to enjoy some scientific credentials, and they have a relatively high level of trust among the public (Jamison 1996). Although NGOs like Earthwatch engage in commercial activities such as marketing to promote their own work and attract volunteers, the shift to commercial companies could be expected to alter this landscape because they explicitly treat conservation experiences as commodities.

The literature on the commodification of nature generally deals with the penetration of neoliberalism into the nonhuman world, whereby markets are created that enclose elements of the environment in order to bring them into the sphere of market exchange (see, for example, McAfee [1999] in relation to biodiversity). Castree (2003) identifies six ways in which nature is being commodified: externally as a resource taken from the environment (like oil); directly as a purchased commodity (such as cylinders of oxygen); by proxy as a characteristic that affects the price of something else (for example, a lake view enhancing house prices); internally by producing new technologies that manipulate the environment (like cloudseeding technologies); in terms of the human body (such as organ trading); and informationally, as knowledge about the environment becomes traded (see also Thornes and Randalls (2007)). Drawing on this literature, it has been argued that ecotourism represents another arena in which nature is being commodified (King and Stewart 1996, Gray and Campbell 2007, Duffy 2008). As an extension of ecotourism, the argument applies fairly well to the current situation with regard to conservation tourism. Private tour operators now dominate the sector, selling conservation experiences as a form of commodity and thus marketing and literally "marketizing" the activity of nature conservation. In what follows, we explore how the commodification of conservation science fits into this schema.

The idea of network governance suggests that, increasingly, a range of actors come together to form "self-organizing, inter-organizational networks" (Rhodes 1996: 660), which are heterarchic (flat) rather than hierarchical, in order to meet challenges that would traditionally have been dealt with by the state. At first glance, the concept of network governance seems to characterize the emerging conservation tourism sector fairly well, as a complex of private and civic bodies come together in the field of nature conservation. The classic critique applied to network governance that the state remains dominant in most governance arrangements (for example, see Davies (2002)) is bypassed in the case of conservation tourism, as it is characterized by very little state involvement (although this does not exclude the possibility of another actor dominating the process). The following explores conservation tourism as a potentially selforganizing environmental governance network, focusing on how networks are formed and maintained in a non-state/market context. The concept of "network" used here is in the sense of "network governance" rather than "network analysis."

As neoliberal processes of privatization and deregulation move resources out of the public realm, regulations concerning their use and exchange become increasingly driven by market forces (Castree 2008). Cashmore (2002) argues that nonstate market-driven (NSMD) governance networks are increasingly common in the environmental field, as networks develop self-regulating mechanisms 
such as certification standards that will protect revenue by convincing customers of their environmental credentials. The emerging literature on legitimacy and certification in commercialized environmental networks argues that the challenge of establishing authenticity across space and time becomes increasingly difficult as environmental governance networks expand to include an ever wider set of actors and organizations. As Eden (2009) shows in her study of the Forest Stewardship Council (FSC) certification procedures, establishing legitimacy is always a negotiated practice. Environmental governance networks are built from diverse elements and new practices are required to validate and support these networks, especially through invoking scientific authority and environmental expertise. Conservation tourism is at a less developed stage, where there is no formal certification, only perceived legitimacy. However, a similar set of questions arises concerning the ways in which scientific legitimacy is constructed and maintained in a highly competitive market.

\section{METHODOLOGY}

In order to access and understand the organizations that make up the conservation tourism industry, we used a qualitative approach drawing upon in-depth interviews with: (1) directors of UK operators and (2) managers of South African conservation volunteering projects. Research was carried out between January 2006 and April 2007, including time spent in South Africa. The United KingdomSouth Africa market was chosen as it is one of the largest and most developed in terms of the global conservation tourism industry, and thus offers insights into the potential challenges raised by this form of conservation in the future (Cousins 2007). Although it is necessary to exercise caution in extending conclusions from what is a highly focused study, general points concerning market forms of environmental governance and the ways in which scientific legitimacy is constructed relate to wider debates within the environmental literature.

The research was designed to capture a representative sample of UK operators and their South African conservation partners. Although the areas of research were known in advance, the exact organizations and actors were not and so a deskbased exploratory phase was incorporated into the earliest stages of the research design in order to identify the exact organizations and actors involved.
This involved a detailed search of web pages (using search engines such as Google and databases such as http://www.responsibletravel.com/), newspapers (in particular, weekend travel supplements), travel and wildlife magazines, and travel books. Organizations were further revealed using a "snowballing" procedure in which operators suggested other operators. The criteria used to select UK operators for this study were that they are registered in the United Kingdom and that they offer at least one international holiday in which the key objective is practical conservation work. This was determined through the operator's websites, and on a number of occasions, by a telephone call to the operator's office. All organizations in this population were approached, and 16 of the 21 identified agreed to participate in the study $(76 \%)$.

The conservation project personnel included in this study were selected on the criteria that they are based in South Africa (which has the largest number of conservation holidays (Cousins 2007, Lorimer 2009)) and that their conservation initiatives are run independently, but they have a partnership with a UK operator who supplies them with volunteers. All conservation holidays (from the 16 participating UK organizations) fulfilling these criteria were shortlisted, amounting to a list of approximately 16 holidays. The UK directors were then approached, and issues of access and finances limited the number of projects visited to four. Nine in-depth interviews were conducted with personnel based in South Africa, including project directors, project managers and country coordinators. A total of 25 interviews were conducted for this study.

Following previous work, UK interviews explored how operator companies were established and subsequently formed networks with conservation projects overseas, focusing on the biographical histories and motivations of key actors (Adger et al. 2002, Borgatti and Foster 2003, Evans 2004). Indepth interviews (Marshall and Rossman 1995, Fontana and Frey 2005) allow these factors to come to light through an exploration of the interviewees' biographies. Semi-structured interviews were largely conducted face to face, but on three occasions by telephone. Each interview was conducted in the participant's working environment; being within the environment of the research was advantageous to gaining insights into the scale of the UK organizations' operations. In most cases, interviews were conducted with the directors of the organizations. Semi-structured interviews ensured 
a consistent range of topics related to the research aims was covered, but also allowed a flexible approach to questioning that gathered opinions and behaviors in the informants' own words (Hurst 2003, Dunn 2005).

Interviews with the South African project personnel explored how and why networks are formed with UK operators and the contractual dimension of these partnerships. Each interview lasted on average between 1.5-2 $\mathrm{h}$ depending on (1) the length of time the participants could devote for the interview, (2) the length of the answers provided, and (3) the extent to which participants were probed beyond the scope of the original questions. Interviews ended with a prompt for additional comments from the participants and were recorded and later transcribed. Basic content analysis was undertaken to capture data for each of the research aims, and to identify emergent themes in the material around each of these (Manning and Cullum-Swann 1994). Interviewing a large proportion of the population of organizations fitting the criteria for inclusion in the study meant that a saturation point was reached after which no new themes emerged (Glaser and Strauss 1967). Using this material, we trace the ways in which conservation tourism is being marketized, and attempt to understand how scientific legitimacy is constructed and negotiated across these different constituencies. Given the sensitive nature of some of the issues surrounding scientific legitimacy and the market motivations of actors within the industry, interviewees were given veto over the use of quotes and semi-anonymity was granted in the sense that no names are used.

\section{THE COMMERCIALIZATION OF CONSERVATION TOURISM}

Conservation volunteering is big business and competition is fierce between rival organizations supplying the package deals. In recent years, there has been substantial commercialization of conservation volunteering both in terms of growth, competitiveness, and niche specialization. In 2005, the number of conservation volunteers guided through UK companies was over three times greater than that of UK non-profit organizations (Cousins 2007). These companies (including Global Vision International (GVI), i-to-i, Real Gap, and Projects Abroad) have seen a definite growth in the number of conservation volunteers and predicted a further increase in numbers the following year. Visions of a largely untapped market and the potential for economic reward have attracted those working within the travel industry. For example, a director of a major gap-year company states:

\section{I've run similar organizations before and we saw a gap in the market... We come at it from a different angle. Our people all have a travel background. So we tend to look at it from the logistics of traveling before the other things, which has enabled us to grow faster I think... in 3 years, it has come a hell of a way. Dramatic. (Interview A [Director, major UK gap-year company], 13 March 2006.)}

Although many of the organizations do not wish to be associated with the tourism industry, the distinction between volunteering and tourism is becoming increasingly blurred. Perhaps the most compelling evidence for the convergence of conservation tourism with the mainstream tourist industry occurred in March 2007 when i-to-i was sold to First Choice Holidays in a deal worth approximately £16 million (Bennett 2007).

Operators in the United Kingdom compete to secure sought-after conservation projects that will attract volunteers. In many cases, they are careful not to advertise details of exact project locations or information regarding the host organization so that volunteers cannot book with the conservation project directly, thus protecting their share of volunteer fees. Their marketing teams devise appealing web pages and glossy brochures mobilizing discrete conservation projects from across the globe, providing a platform from which prospective volunteers can buy a conservation experience. Organized by region, activity, price, and trip duration, volunteers can search for their perfect project. Organizations make full use of the charismatic species and exotic destinations offered, through dramatic close-up photography and images of volunteers touching and holding African lion (Panthera leo) cubs, or Costa Rican sea turtle (Dermochelys coriacea) hatchlings, for example. Volunteers may find themselves paying more for projects with high-end charismatic species, such as lions, cheetahs (Acinonyx jubatus), leopards (Panthera pardus), and dolphins (Delphinidae family).

Vital to the success of the conservation tourism industry is that the conservation products offered 
are seen to be of genuine conservation value, and operators try to balance this conservation merit against the attractiveness of the projects for volunteers. As one marketing manager puts it: "It needs to be a balance. It needs to be something that is going to excite people and they have got to want to go and do it, but it has also got to be of conservation value and we try our damnedest to get that conservation value there." (Interview C [Marketing Manager, major UK gap-year company], 13 March 2006.)

This ambivalence also came through in the reasons that directors were operating in the sector. For example, one director explains: "Well, we are a profit-making company. But that wasn't the only motivation." (Interview A [Director, major UK gapyear company], 13 March 2006.) Another says "We won't set up projects artificially because we want to be somewhere. Let's say the next big place was Kyrgyzstan and there were no big projects to work with, we wouldn't go and set one up just to cater to those needs." (Interview B [Director, major UK gap-year/travel-experience company], 3 May 2006.)

Negotiating the conservation element of projects requires a number of balances to be struck. Competition between projects is intense and those that sound less interesting to potential volunteers, however scientifically valid, may simply not get enough members of the general public prepared to pay for the experience. The desire for charismatic megafauna, physical contact with species, and appealing destinations limits the types of conservation projects that can be taken on by the UK operators, in particular those who are marketing to a more mainstream market. As one director puts it:

You know, I could have a very genuine proposal for research into dung beetles in the Democratic Republic of the Congo, and I could say to them, there is no way we are going to get anyone to do it... So that is in some ways the sad side of it, valid projects that are offered... But that is not what we are about and we have to accept that some things just aren't going to work. So it's two sides: can we get the volunteers, and is the project valid? (Interview G [Director, major UK volunteer company], 30 March 2006.)
New projects need to be able to compete with the projects already offered by the UK operators and with the vast array of exciting and appealing projects to chose from; genuine conservation projects that cannot compete get left behind. Scientifically valid projects that appear to be less attractive to volunteers may still be considered by some organizations, however, if they can be adapted to make them more appealing. One marketing manager explains: "Something like studying grasses... We would try and see if there are ways of making it more exciting -if there is a way they can add species or look at a different aspect of the environment... We would try our hardest. But really it has to be a balance." (Interview C [Marketing Manager, major UK gapyear company], 13 March 2006.)

This disparity between conservation work and what conservation volunteers desire leads to the conservation element of some projects being diluted in favor of more volunteer-friendly activities and species. As Lorimer (2009) and Cousins (2007) have noted, this lends a decided skew to the range of species and habitats that conservation tourism tends to favor, with an emphasis on charismatic megafauna. Researchers often add species that will be popular with volunteers to their program, which ultimately reduces the resources spent on the focus species. The preferred methodology may also have to be compromised in consideration of the volunteer's interests. As one director explains: "I can't get volunteers to go and survey dung beetles, but I can get volunteers to go and survey small mammals. So you are not always using the most efficient techniques. You have to use what's possible." (Interview L [Director, major scientific/ conservation volunteer company], 8 March 2006.) Not-for-profit organizations such as Earthwatch, who receive funding from other means such as businesses and governments, can sometimes support those important projects that are less attractive to volunteers, and Operation Wallacea sometimes pays scientists to carry out essential work that they cannot sell to students.

There is a large demand for suitable new projects and, in some cases, a number of international companies supply volunteers to one project. In popular areas, such as the Limpopo district in South Africa, there is overcrowding, with large numbers of projects running per wildlife ranch as all available options are utilized by operators. A number of projects were taking on more volunteers than were actually useful. In search of new opportunities, 
volunteer use has extended into adjunct activities such as game capture in South Africa. This is leading to questions of where conservation science ends and in the case of game capture, where stock management begins. There has also been a dilution of conservation projects, with projects such as: "sea turtle and surf in Costa Rica," "African horseback and conservation experience," "South Africa conservation education through photography" (ww w.realgap.co.uk) and "wildlife film academy" ( $\underline{\mathrm{wW}}$ w.worldwideexperience.com).

Potential volunteers are enticed by physical engagements with nature but also the anticipated worthiness of projects and the importance of their own role. This is enhanced and reinforced by the use of language in marketing materials such as: "work very closely with the wildlife," "heavily involved" (www.gapyearforgrownups.co.uk), "get close to wild animals," "get up-close and personal," "hands-on conservation" (www.realgap.co.uk), "make a genuine difference," "work on the frontline of conservation" (www.gvi.co.uk), "playing an active role" (http://www.conservationafrica.net/), "worthwhile conservation," and "meaningful conservation" (www.i-to-i.com). Genuine conservation is a major selling point, and organizations design their websites and brochures to enhance their credibility. "If you read the project descriptions on our website, a lot of them aren't just about you can come and play with our animals - it has as much of the conservation stuff in as possible... It's "why are you working with elephants?," "why are you taking this data?"" (Interview C [Marketing Manager, major UK gap-year company], 13 March 2006.)

Some companies seemed wary of appearing too glossy. For example, one company's director states: "We have a very detailed website, which is just being updated. It's information packed. I don't think it should look too slick [emphasis added]." (Interview L [Director, major scientific/conservation volunteer company], 8 March 2006.) Detailed information and scientific-sounding jargon in the project descriptions add credibility to the projects and reassurance of their worth. Examples of language used in the project methods include: "fecal analysis," "mammal census" (www.realgap.co.uk ); "statistically rigorous mark-recapture methodologies," "remote-photography surveys," "investigations" ( www.worldwideexperience.com); "monitoring range utilization," "GPS recording of midden sites" (http ://www.conservationafrica.net/).
There is a high degree of niche specialization in the sector, and specific groups of the general public are targeted by the marketing teams. Operators can be secretive about their marketing methods, each having their preferred combination of methods for targeting their chosen groups. A major form of advertising is through their own websites and websites such as www.responsibletravel.com and www.findagap.com, which advertise a wide range of projects from different organizations. One director refers to growing competition within the industry and the increasing pressure on organizations to adapt and change:

You have to treat it commercially. Because if you want to support the project that you are working with then you have to advertise... I think there are a couple of really good quality organizations that are being left behind now because they just can't keep up... Getting into it late 90s [sic] was a good time because there were not that many. Getting into it now, unless you are putting a huge amount of money into your key-word optimization then you are only going to come on page 10 of Google and no one is going to see you. (Interview G [Director, major UK volunteer company], 30 March 2006.)

The fact that search-engine optimization can make or break an organization demonstrates the commerciality of the industry. Operators are quick to colonize new niches and make the most of every opportunity. For example, one organization has formed networks with educational organizations from their U.S. office that allow them to give college credit for American students on their programs. This market has expanded as students get tax relief from governments. Another operator has used the legitimacy of its employees as academics to recruit university students needing research projects for their dissertations. Within an organization, there is variation between international offices regarding what is popular with volunteers (Cousins 2007). Americans tend not to travel as far, mostly going to Latin America. The causes for this are often practical as well as cultural, with cheaper flights and shorter annual leave dictating a very different market.

The ability to adapt and find new avenues is seen as essential to keeping up with the growth of the industry. But, at the same time, operators are fairly 
reflexive about a number of balances that must be struck: between the attraction of the projects and their scientific credibility, between the exoticness of a destination and the practicalities of working there, and between the type of volunteer and their capacity to carry out meaningful conservation. One company stated that they don't offer 2-week breaks because it is impossible for a volunteer to do something valid in such a short period of time. Each of these balances represents a practical dimension of the larger tension between tourism and conservation, and, to some extent, niche differentiation within the sector appears to be driven by how different tour operators strike these balances. The way in which these balances are made seems to depend on the specific organization, which in turn is linked to the question of who is forming the companies and how they are forging networks with conservation projects overseas.

\section{THE CONSERVATION TOUR OPERATORS}

The UK conservation volunteering industry is made up of a huge variety of organizations (see Cousins 2007); for some, conservation and scientific research have been the motivating force behind the organization, whereas for others, providing the volunteering experience has taken center stage. This diversity is reflected in the considerable assortment of backgrounds and motivations of the founders. Here, we focus on the commercial operators whose founders are largely a mix of former academics, ecologists, and environmental entrepreneurs. Next, we provide a brief description of the origin of some of the major UK companies within the conservation volunteering industry, before moving on to focus on how the networks forming the industry are constructed and negotiated.

Operation Wallacea conducts ecological surveys overseas with the assistance of university students as volunteers. The idea for the company was conceived by a former academic based on the strength of British ecological surveying and the British tradition of volunteer work. The founder wanted to replicate the British approach to surveying in regions that had no formal species lists. Projects Abroad (formerly Teaching and Projects Abroad) originally started as a teaching program. The current director was an academic geographer who had links with universities in Eastern Europe. On realizing the demand for English teachers in Eastern Europe, he initiated the provision of
English-speaking volunteers and Projects Abroad was born. The company later grew to include other volunteer opportunities, including conservation work. The founder of $i$-to-i also realized the demand for English speakers overseas following her travel experiences teaching English in Japan, China, and Greece. The organization later expanded to include a vast array of travel opportunities.

The founders of GVI were also inspired by their own experiences; GVI was set up by an entrepreneur and a marine biologist in realization of an untapped niche. Their aim was to set up an organization that could be approached for support in the form of volunteers and finances. The idea for the company The Leap was inspired by the founder's gap-year experience (working in a safari camp) and influenced by his later experience of working for a small travel company. The director of Real Gap previously worked in the travel industry and founded Real Gap after realizing a gap in the market. He later established Gap Year for Grown Ups to appeal to the older volunteer.

Other founders set up their organizations after arranging work experiences for their friends or family. The current director of Outreach International was working in an environmental consultancy in Mexico when he happened upon a project that needed volunteer support. After organizing for a friend's daughter to volunteer on the project, demand ensued and the company grew and expanded. African Conservation Experience was founded after the current director organized a work experience for his son on a game reserve.

The conservation product is created when a partnership is formed between the UK operator and an international conservation organization. This is a two-way dynamic, driven by demand from operators in the United Kingdom and the supply of conservation projects in South Africa. The mainstreaming of conservation volunteering has expanded the number and range of networks as operators strive to differentiate themselves from their competitors and provide original and more adventurous experiences. Established organizations such as ACE, Greenforce, GVI, and i-to-i receive a large volume of requests for volunteers, having been discovered through a variety of means including word of mouth, internet, magazines, and television. In addition to receiving project proposals, UK organizations often actively search for projects in a destination that they are interested in. As one 
director says: "We work with people in every country that we go to and they work with us to talk to projects... Sometimes we pursue something because we know that it's of interest. And sometimes people come to us with an idea-we get a huge amount, both through our contacts in country and direct to us." (Interview B [Director, major UK gap-year/travel-experience company], 3 May 2006.)

A number of organizations employ country coordinators who search for new projects and carry out initial assessments: "It's a phone call and a chat and a look at a website or some photos and then if he thinks it viable he will then go out and do a site visit and then go from there. Generally he will know from a phone call if it's going to be a good project." (Interview C [Marketing Manager, major UK gapyear company], 13 March 2006.)

Rather than an organization managing hundreds of projects, local teams manage the projects on their behalf as they know the country better. Other operators employ UK staff to search for projects, but country knowledge remains important: "So the African program manager traveled around, found the projects that we wanted to work with-made deals with them. Right now, we have our China manager in China doing exactly that, trying to find new projects. Our Australia manager is in Australia looking. We are constantly looking." (Interview A [Director, major UK gap-year company], 13 March 2006.)

There is a clear resonance with the postcolonial conquest of nature in the way many of the companies talk about finding projects, and it is not a huge metaphorical leap to talk about their expansion in terms of the exploration of uncharted territories in order to "capture" exciting projects. Why organizations choose to form specific networks is determined by a number of factors. Previous experience of a country and personal contacts are extremely important factors, and have influenced the initial direction of a number of organizations. For example, one director notes: "Friends, networks. Well, the Africa ones were fairly easy because that is where I come from. South America, I went to the World Travel Market and met people there and that's how it developed really." (Interview D [Director, UK gap-year company], 21 March 2006.) In some cases, arranging for a family member to volunteer has led to an interest from friends that has gradually developed into the growth of an organization. Often in the initial stages of an organization's development, there may be a personal desire to work in a particular region, leading to the use of a country that would not normally be seen as an obvious choice of destination. For example:

If you go to somewhere like Cambodia, they (projects) are dotted around and it's all about personal contacts and it's difficult finding the places unless you speak Khmer and know your way around. I don't know how anyone could start there. Somewhere like Costa Rica, you go there and it's very volunteer friendly-it's very clear how you get your visa and you can learn Spanish... You know, there are nicely managed language schools with a clear program. In Cambodia, you have to do everything yourself. (Interview E [Director, UK gapyear company], 21 March 2006.)

There is thus a personal element to many choices. The motivation for working in Cambodia was because this person "wanted to support it," but increasingly, projects are chosen based on their perceived salability to volunteers. Organizations seek out projects that will satisfy their strategic goals, such as adding topical projects (for example, climate change) or those that will assist them to expand into a new market. One director believes that his organization has an impact on where other organizations go: "It's amazing how if we open a project somewhere the other organizations will follow... People are looking for... something different. Everybody would like to be a trendsetter, whether or not you get it right." (Interview B [Director, major UK gap-year/travel-experience company], 3 May 2006.)

The practicalities of a location for both the UK operator and also the volunteer play a major role in the choice of project. Some destinations such as the Democratic Republic of the Congo are ruled out on safety grounds, whereas other locations such as the Antarctic are dismissed based on the logistics of operating there. Global Vision International cited cost for the volunteer as a criterion in selecting projects. Accommodation needs to be affordable in order to keep the overall cost of the experience within price range. There is a need to provide suitable lodgings and facilities for volunteers. Some organizations feel that they can do this most effectively by running the projects themselves. For 
example, one director says: "If we say to some environmental organization in Mexico for example, "hey, how about we buy some places on your scheme?," I think it would be a disaster. People would be quite cross because they could buy it themselves." (Interview F [Director, major UK gapyear/travel-experience company], 15 March 2006.) Organizations need to make sure that the volunteers will have conservation tasks that they can be trained to do rapidly. One director states the need to make sure that the amount and nature of work is right for the people that are their market: "It needs to be general work that everyone can do." (Interview B [Director, major UK gap-year/travel-experience company], 3 May 2006.) Volunteers may be doing a range of placements through the same organization (for example, teaching English) and may have no previous knowledge or experience in conservation sciences. In fact, most conservation projects underway across all of the organizations interviewed have no prerequisites.

\section{FORMING LINKS WITH CONSERVATION PROJECTS}

The conservation projects within our sample are all run by South Africans and are all registered companies, with the exception of one registered nonprofit organization. Members of the game capture team have no scientific credentials and are largely self-taught in the methods of catching game. The other three projects are located within private wildlife ranches and a national park, and the work largely involves the monitoring of wildlife and some general ecological management. Two of these projects are managed by people with scientific qualifications and research experience. The other project is run by someone with no formal conservation qualifications but many years of experience working as a ranger. A high motivating factor driving these projects is the lifestyle that they provide (the opportunity to work in nature) in addition to a source of income. One organization, however, was largely motivated by their long-term research aims.

The projects (with the exception of game capture, which operates with or without volunteers) were set up on the basis that they would use volunteers as the major source of funding. The volunteer's fee generally covers the basic running costs of the projects including staff salaries, project equipment, and food for the volunteers. Without the resources to effectively source volunteers themselves, the conservation initiatives make use of the UK operators' marketing power. As one project manager puts it:

Obviously, in order to get a project like this going, they have to get some funding in, the only option was to go the volunteering route, to make money. I've been involved with research where it is sponsorship based and it has never worked out... We need them because we don't have the ability to market ourselves. (Interview I [Director, South African wildlife management services company], 29 November 2006.)

Word of mouth plays an extremely important role in creating partnerships with the international operators. This is especially the case in provinces such as Limpopo, where there is a high concentration of game ranches and projects. Chance meetings with country coordinators have led to partnerships being formed, as was the case between a game capture team and a UK operator: "We offloaded animals in Shamwari from the trucks and they have students there and they said that looks more interesting than work on a nature reserve... coz [sic] they are just working there. And that's where everything started. We never knew there was something like that." (Interview H [Manager, South African game-capture company], 19 March 2007.)

Project managers are often not aware of the concept until they are approached. Others formulate project proposals based on knowledge of these organizations as a potential funding body and source of income. Some already have contacts in place through previous work experiences, whereas others must seek out potential partners. For example, one South African project director approached a UK operator at a travel fair in London having previously heard about such organizations:

I gave them a proposal and told them what it was all about and they were pretty keen on it. And we obviously got hold of a whole bunch of companies that were prepared to do it you know. But this company is quite big and probably the biggest supplier at the end of the day. Basically it came down to the number of people that they could supply the soonest. (Interview I [Director, South African wildlife management services company], 29 November 2006.) 
In this case, the speed at which the UK operator could supply volunteers and the numbers they could produce was the clincher. It is the UK operator who largely determines the deal that is made between themselves and the conservation initiative; they set out the terms of the partnership. As one manager of a South African organization puts it: "There was no negotiation. They said this is what we do, and I said fine, that doesn't bother me as long as we can cover costs for food and all that stuff that is all that matters." (Interview K [Project Manager, South African ecological management services company], 31 March 2007.) Similarly: "It was obviously a mutual thing - we both decided on the same thing. Again obviously they are quite big players and dictate what you are going to do." (Interview I [Director, South African wildlife management services company], 29 November 2006.)

This does, however, lead to some project managers becoming dissatisfied with their share of the deal. However, in some cases, it is the project director who decides on the amount of money they would like to receive per volunteer. For example, one director explains: "All I had to do was name my price and they added their commission. I had to sign documents and help them with their website, with wording and pictures, and at no time felt I was getting into something I didn't like. We have worked together for the last 6 years." (Interview N [Director, South African wildlife research organization, nonprofit], 25 April 2007.)

This greater flexibility toward finances appeared to create a stronger partnership with less tension. The amount that the projects received from the UK operators (or in some cases, the country coordinators) varied between projects (£120-£250 per student per week) reflecting differing percentage cuts of varying project fees.

A memorandum of understanding usually sets out the conditions of the partnership between the project and the operator (or country coordinators) so that everyone knows what is expected of them, including the obligation of the project to the operator, the obligations of the project to the volunteer, and the obligations of the operator to the project. Some of the relationships are of a more casual nature, however, with mutual trust substituting for contractual obligations:

Up until now it has all been verbal, which is cool. Because I know Hannes [sic] and
Sean [sic], we have unsaid things, project rules and stuff like that. Yeah, there is obviously going to be a courtesy thing involved. In the past, we have discussed 2 months' or 3 months' notice if either of us wanted to pull out. (Interview K [Project Manager, South African ecological management services company], 31 March 2007.)

Similarly: "No, I've got no idea... they just came out and see us... you know we are not people that believe in contracts. If we can't do honest business, we leave it." (Interview H [Manager, South African game capture company], 19 March 2007.)

According to project directors, it usually takes around 6 months to a year from first correspondence with an operator to receiving volunteers. In this period, projects are visited and assessed by a number of staff. As one project manager explains:

They wanted certain things in certain ways. Hannes [sic] (UK director) came out and looked at it himself-he wanted to make sure that they would be getting proper genuine conservation experience out of itnot just a game viewing thing. Sean [sic] (South African coordinator) came out and Laura [sic] (UK marketing manager)... the one who goes to universities and tells people about it... she came out here in September and had a look as well so that basically she could tell them what to expect when they arrived. Now ACE is starting a whole new safety policy, which is why we have had this safety company out here as well. (Interview K [Project Manager, South African ecological management services company], 31 March 2007.)

In the case of the game capture project, in order to understand and assess the experience fully, the son of the UK director joined the game capture team for 2 months before any volunteers were sent. Operators may also help with start-up costs, such as furnishings for the volunteer accommodation.

Generally, the South African project directors and staff were positive about their relationship with the UK operators on a personal level, but also more broadly. For example, one director states: "There is a whole bunch of reserves that do it. Um, yeah, it is definitely increasing. It helps a lot. The government 
are quite keen on it." (Interview I [Director, South African wildlife management services company], 29 November 2006.) Forming partnerships with UK operators is seen as a fairly reliable source of funding (as opposed to relying on donations) and also a hassle-free way of receiving regular volunteers. As one manager puts it:

The positives are guaranteed marketing... and we don't have to put anything into marketing. The fact that they can get us six volunteers, which is about $80 \%$ of what we need. So we can survive. It is our bread and butter. And also in terms of getting people to the project, there is no fuss or hassle. (Interview J [Project Manager, South African wildlife management services company], 27 November 2006.)

Not only do the projects appreciate the partnerships for the stability that they offer, but they also appreciate the company of the volunteers. One director described how the volunteers made the research house "feel alive." Although project directors and managers were generally happy with the number of volunteers supplied, project directors spoke of sometimes feeling obliged to take on more volunteers than they would really like in the peak season (June-August). Out of season (particularly Christmas time), some projects suffer from a lack of volunteers. The general view was that if additional funding was obtainable, volunteer numbers would be limited. As one director explains: "If we get substantial funding, I would like to limit volunteers to three even in peak times and set 8week expeditions. The staff like the volunteers, but if too many and if they are there for longer than 8 weeks then fighting in the house starts as personalities between people start to grate." (Interview N [Director, South African wildlife research organization, nonprofit], 25 April 2007.)

The type of volunteer received (e.g., biologist or accountant) was generally seen as unimportant, as long as they were keen to help out. In addition to issues relating to finances and volunteer numbers, other shortfalls spoken about include inaccurate marketing of projects and a lack of information on the volunteers before arrival. Although largely happy with the actual service, one project manager spoke of feeling trapped in a contract that he was not entirely happy with:

There have been negotiations and he has been trying his hardest to get more. I don't think $30 \%$ is fair. But obviously we need them because we don't have the ability to market ourselves. I think it is quite a tender situation. If you go and approach another big company and tell them that you are interested and word gets out and (the UK operator) drops you, then you have nothing. (Interview J [Project Manager, South African wildlife management services company], 27 November 2006.)

In this situation, the project has set up their own website in the hope of attracting some additional volunteers of their own. In fact, most projects have their own websites advertising for volunteers, giving them the opportunity to earn more and feel more independent. The use of multiple operators from one or more countries is preferred by some projects as again it allows them to be less dependent upon one source of volunteers and achieve a larger overall number of volunteers. For example, one director states: "It's nice to just keep that option open you know, for future plans. You never know what is going to happen... with world markets." (Interview I [Director, South African wildlife management services company], 29 November 2006.) This can lead to the same project being advertised with two or more operators. Most UK organizations, however, prefer to have exclusivity over projects. As one director puts it: "Not for any selfish reasons, because (a) we can provide the right number of volunteers for them and (b) that is the way we like to operate. Otherwise you get different arrangements." (Interview B [Director, major UK gap-year/travel-experience company], 3 May 2006.) Certainly, it becomes more difficult to inform volunteers of the maximum group size they should expect if other organizations are supplying volunteers, and volunteers may find that they have paid varying amounts for the same project, causing friction within the group.

\section{SCIENTIFIC LEGITIMACY UNDER MARKET CONDITIONS}

Despite the balance that must be met in order to sell projects, volunteers expect the projects that they participate in to have genuine conservation value. As the conservation volunteering sector becomes more commercialized, it might be expected that this process becomes more fraught. The question of how operators determine the scientific legitimacy of potential conservation projects is an important one. For some, common sense, experience, and the 
ability to distinguish genuine projects from counterfeit are seen as the essentials when determining project quality: "I think if we can understand it and they are not trying to pull the wool over our eyes as they sometimes try to do... And that is not necessarily about being an environmentalist -it's about having some common sense." (Interview E [Director, UK gap-year company], 21 March 2006.)

\section{Similarly:}

There are a lot of pirates, there are a lot of cowboys. I mean it's a money-making thing nowadays. You get people that are just like "yeah, people can come and dart an elephant once every 2 weeks or something'... You don't have to treat every proposal with suspicion, but I do believe you need to look very hard into it. Because it is now known as an industry where you can make a lot of money. (Interview G [Director, major UK volunteer company], 30 March 2006.)

In popular regions such as South Africa, volunteer projects with little or no conservation value have been set up by individuals as a steady source of income. Spurious conservation projects, such as caring for lion cubs in a lion-breeding center (where the lions are being bred for canned hunting) have in the past been supplied with international volunteers.

The conservation work simply being relevant to the people conducting the conservation work is important to one director: "I don't really look and think is this good quality or not. I just look and see what they are doing and if it is relevant to them, then that is good enough for me. I' $m$ not trying to reinvent the wheel." (Interview D [Director, UK gap-year company], 21 March 2006.)

Similarly, one director, in defense of the quality of their conservation projects, dismissed any criticism of their projects as criticism of international conservation methods: "In my experience, conservationists amongst themselves can't agree what is right. If a British conservationist wants to say what the Ecuadorians are doing is wrong then so be it." (Interview B [Director, major UK gapyear/travel-experience company], 3 May 2006.) These quotes demonstrate the potential difficulties of regulating the consistency of the conservation science that occurs under the aegis of conservation tourism. Criticism of conservation projects in different countries implies that there is a correct way of undertaking conservation, imposing knowledge from certain places (usually in the developed global North) over another (usually in the less developed global South). The realpolitik of conservation tourism is best summed up by the director quoted above, who claimed: "If it is relevant to them, then that is good enough for me."

Despite the challenges of regulating standards of consistency across such a dispersed network, a number of organizations do attempt to provide a more objective measure of scientific rigor. More scientific organizations such as Blue Ventures, Earthwatch, Biosphere Expeditions (nonprofits), and Operation Wallacea use personal academic expertise and/or the peer-review process to determine the scientific quality of their research. One organization measures the quality of their conservation by their outputs. As the director explains: "We peer review at the output stage. Where you get the papers coming out. If the papers aren't coming out and getting published, we chop the scientist and we get another one, because they are not producing the goods as far as we are concerned." (Interview L [Director, major scientific/conservation UK volunteer company], 8 March 2006.)

Most companies simply aim to provide project updates both for potential and past volunteers to browse. Operation Wallacea believes that the quality of an organization's conservation work should not only be judged by its outputs, specifically the number and quality of the peer-reviewed papers being produced, but also how that science is being used for conservation. There is tension between a number of operators over the quality of conservation being conducted, particularly in light of the recent growth of the industry. For example, as one director states:

There are a lot of organizations popping up who don't perhaps have best interests for the environment or the community at heart and that could give the volunteer industry a bad name. And if the volunteer industry gets a bad name, then we really have to make sure that we are standing up on our soap boxes, saying no we are not like that. (Interview G [Director, major UK volunteer company], 30 March 2006.) 
The impact of these companies on the reputation of the industry is a concern and several organizations would like to see further regulation within the industry and the "poorer quality companies being weeded out." (Interview C [Marketing Manager, major UK gap-year company], 13 March 2006.) Currently the Year Out Group (YOG), a selfgoverned regulatory group, offers a standard within the industry. Members adhere to a code of practice, terms, and conditions, provide annual accounts, have a crisis and risk policy in place, and have public liability insurance of $£ 2$ million (YOG 2008). The YOG offers reassurance to volunteers when choosing to volunteer through a YOG-affiliated organization, but does not assess the quality of the conservation work nor the methods for monitoring quality, and there are concerns within the industry that volunteers may find it increasingly challenging to distinguish which projects offer genuine conservation: "You know, despite being for good causes, they are businesses and there is a lot of competition between them. I wish the whole thing was more open... People have a battle nowadays working out which are the valid projects and which are the cowboy ones, because there is so much on offer." (Interview G [Director, major UK volunteer company], 30 March 2006.)

Developing a scientific standard is complicated by both the looseness of links between the people selling the conservation tours and those conducting the conservation, and the pragmatic balances that have to be struck between scientific rigor and the creation of a desirable experience. Having said that, the biggest limiting factor at present is probably the overall size of the industry, which does not yet generate enough revenue to support the creation of a self-financing international certification scheme, such as that found in the forestry sector.

\section{CONSERVATION SCIENCE AS COMMODITY}

Conservation tourism is characterized by a number of thin networks linking operators and projects, which lead to multiple truth claims both within and between networks as different groups build their own versions of legitimacy. Although the sector is still emergent, there is a clear power differential within this relationship. Because conservation projects rely on tour operators for a funding stream in the form of volunteers, they are essentially regulated by those operators, who decide whether a project is suitable to take on or not. This situation resonates with the issue of donor control among development NGOs, who lose sight of their own strategic goals trying to respond to those of their funders. The aspects of conservation tourism described in this paper are obviously a fair way from the kinds of network governance outlined at the start of the paper that are characterized by "flat" power relations, displaying a clearly defined hierarchy.

But this type of problem occurs in "normal" (nonmarketized) conservation too. Conservation work has traditionally focused on certain elements of the nonhuman world, from charismatic megafauna to specific animals that have value within a certain culture or country. This bias can be traced from the Convention on Biodiversity through to the Local Biodiversity Action Planning process in the United Kingdom, which brought volunteers together to coordinate conservation at the local level and tended to be highly variable in terms of the species and habitats that receive attention (Evans 2004). It could be argued that consumer-driven conservation is not qualitatively different to "traditional" conservation, and that, by making the emotive aspects of conservation explicit, it prompts a more honest and explicit engagement with a tension that is often conveniently forgotten by conservationists. In this sense, commodification can be seen as a new medium through which values about nature are translated into scientific priorities, rather than offering a qualitatively new mode of valuing nature.

Having said this, the fact that science is quite literally "consumed" by conservation tourists does indicate a departure from traditional conservation, leading to a kind of customer-contractor relationship between conservation science and the paying public (Demeritt 2000). Returning to Eden's (2009) arguments, whereas claims to scientific credibility constitute authentification, the way in which it is achieved is largely opaque. Conservation tourism produces a classic commodity fetish around the notion of "science," as "blackboxing" (Latour 1993) legitimizes conservation in order to underpin sales. Science as a guarantor of objectivity and legitimacy is transformed from a power fetish into a commodity fetish. The blackbox of science within these networks is a vehicle through which scientific and market logic converge under neoliberalism.

Turning the question around, are the types of market relations constructed around conservation radically different? In terms of Castree's (2003) six-fold 
typology, conservation tourism represents a twoway commodification of external nature (the actual animals and habitats in which the holidays take place) and information about that external nature (the scientific expertise of the projects). Indeed, the research that this paper is based on suggests a seventh form of commodification based on selling a particular "experience" of nature (the affective economy of conservation tourism). Scientific legitimacy transforms the experience of external nature into a different commodity from that offered by straightforward ecotourism, and is one of a plethora of emergent industries commodifying what could be termed "environmental experiences."

Mansfield (2007) has argued that there are actually multiple neoliberalisms, which produce differing patterns of commodification and privatization. Some of the companies discussed in this paper are what could be called commercial setups "with a heart," often cast in the image of their founders who are both business entrepreneurs and conservationists. In this sense, market relations are tempered by underlying ethics and represent a defensible, if highly diverse and informal, regulator of projects. As the quotes from tour operators and project managers demonstrate, they do, however, display a degree of reflexivity concerning their own operation and the role that science plays in that process. Many operators themselves will compromise scientific principles for locally relevant interventions, and deploy locally derived criteria for validity that conform more to a model of sustainability than scientific rigor. In these cases, conservation tourism produces a more locally engaged and "sustainable" scientific process. Further research is required into the ways in which more organic and locally responsive models of conservation tourism operate. Such work would be of value in exploring how simple analytical distinctions between marketdriven governance (i.e., private, commercial) and non-market-driven governance (i.e., NGO, charity) are breaking down in practice, as hybrid organizational forms emerge.

On the other hand, the opinions of some tour operators suggested that large economic interests may increasingly come to control the sector in the future, in much the same way that major supermarkets control supply chains now, raising a series of different challenges related to the regulation of larger companies operating in environmentally sensitive industries. In light of this possibility, further research could fruitfully be undertaken examining the models of portfolio management that are used by larger operators, in order to develop guidance for corporate responsibility in the sector.

\section{CONCLUSION}

This paper has used conservation tourism to explore the commodification of conservation science. Scientific legitimacy authenticates conservation tourism and is constantly balanced against the quality of the volunteer experience, and many of the companies in the sector are highly reflexive about this tension, both in terms of their own practices and those of their competitors. Authenticity is seen as a selling point and as a point of principle to the organizations, underpinning the financial and moral economy of conservation tourism. Rather than being reduced to the logic of the market, the desire for authenticity remains in tension. It is constructed and contested within conservation tourism networks and atomized throughout a transnational network of actors who are both scientists and business people, and who rely on personal and professional opinions and relations. Market share is based on achieving a balance between maintaining scientific credentials and appealing to the emotive needs of volunteers, all in as cheap a way as possible. This tension has driven the emergence of hybrid organizations within the sector, as a spectrum of companies coexist with varying orientations toward commerciality and conservation.

It is hard to generalize about either the quality of the conservation science being sold, or the future of the sector, both of which are important questions given its continued growth. Many directors suggested that the sector will become increasingly dominated by large corporate travel organizations in the future, as the industry comes onto the radar of mainstream tour operators. This scenario presents a number of challenges for the sector. For example, under neoliberal conditions does science become another unequally distributed resource? Conservation tourism already has a similar geography to that of ecotourism, with visitors (generally from the developed global North) paying to work on conservation projects (generally in the global South). As Duffy (2008) argues in relation to Madagascar, the control of knowledge and resources tends to remain in Western hands, as the conservation projects themselves are typically set up and administered by Westerners for Westerners. 
The UK tour operators essentially regulate projects in South Africa, as they hold the purse strings.

If conservation tourism is to become an equitable mechanism for global conservation, then the progressive commodification of conservation will need to be tempered by some form of regulation. In this sense, conservation tourism recapitulates debates occurring across a number of environmental fields concerning the degree to which market mechanisms can be manipulated to deliver sustainable solutions to governance challenges. These questions are critical to the development of what has the potential to be an important resource for global conservation.

Responses to this article can be read online at: http://www.ecologyandsociety.org/voll4/iss 1/art32/ responses/

\section{Acknowledgments:}

The research for this paper was funded by a PhD scholarship in GEES at the University of Birmingham and NERC/ESRC grant PTA-036-2006-00017. The authors wish to thank all those who gave their time to be interviewed.

\section{LITERATURE CITED}

Adams, W. 1997. Rationalisation and conservation: ecology and the management of nature in the UK. Transactions of the Institute of British Geographers 22:277-291.

Adger, W., K. Brown, J. Fairbrass, A. Jordan, J. Paavola, S. Rosendo, and G. Seyfang. 2002. Governance for sustainability: towards a "thick" analysis of environmental decision-making. Environment and Planning A 35:1095-1110.

Bell, S., M. Marzano, J. Cent, H. Kobierska, D. Podjed, D. Vandzinskaite, H. Reinert, A. Armaitiene, M. Grodzinska-Jurczak, and R. Mursic. 2008. What counts? Volunteers and their organizations in the recording and monitoring of biodiversity. Biodiversity and Conservation 17 (14):3443-3454. DOI 10.1007/s10531-008-9357-9.
Bennett, R. 2007. Gap-year companies to face tough controls on dubious charity work. The Times Online. [online] URL: http://www.timesonline.co.uk/ tol/life and style/education/student/article2280604. ece. Accessed 18 August 2007.

Blamey, R. 2001. Principles of ecotourism. Pages 5-22 in D. B. Weaver, editor. The encyclopedia of ecotourism. CABI International, Wallingford, UK.

Borgatti, S., and P. Foster. 2003. The network paradigm in organizational research: a review and typology. Journal of Management 29(6):991-1013.

Broad, S. 2003. Living the Thai life: a case study of volunteer tourism at the gibbon rehabilitation project. Tourism Recreation Research 28(3):63-73

Caissie, L. T., and E. A. Halpenny. 2003. Volunteering for nature: motivations for participating in a biodiversity conservation program. World Leisure Journal 45(2):38-50.

Campbell L. M., and C. Smith. 2006. What makes them pay? Values of volunteer tourists working for sea turtle conservation. Environmental Management 38(1):84-98.

Cashmore, B. 2002. Legitimacy and the privatisation of environmental governance: how non-state market-driven (NSMD) governance systems gain rule-making authority. Governance $\mathbf{1 5}$ (4):503-529.

Castree, N. 2003. Commodifying what nature? Progress in Human Geography 27(3):273-297.

Castree, N. 2008. Neo-liberalising nature 1: the logistics of de- and re-regulation. Environment and Planning A 40(1):131-152.

Coghlan, A. 2008. Exploring the role of expedition staff in volunteer tourism. International Journal of Tourism Research 10:183-191.

Cousins, J. 2007. The role of UK-based conservation tourism operators. Tourism Management 28: $1020-1030$.

Davies, J. 2002. The governance of urban regeneration: a critique of the "governing without government" thesis. Public Administration 80 (2):301-322. 
Demeritt, D. 2000. The new social contract for science: accountability, relevance, and value in US and UK science and research policy. Antipode $\mathbf{3 2}$ (3):308-329.

Duffy, R. 2008. Neoliberalising nature: global networks and ecotourism development in Madagascar. Journal of Sustainable Tourism 16 (3):327-344.

Dunn, K. 2005. Interviewing. Pages 192-206 in I. Hay, editor. Qualitative methods in human geography. Second Edition. Oxford University Press, Oxford, UK.

Eden, S. 2009. The work of environmental governance networks: the case of certification by the Forest Stewardship Council. Geoforum, in press.

Evans, J. 2004. What is local about local environmental governance? Observations from the local biodiversity action planning process. Area 36 (3):270-279.

Fontana, A., and J. H. Frey. 2005. The interview: from neutral stance to political involvement. Pages 695-727 in N. K. Denzin and Y. S. Lincoln, editors. The Sage handbook of qualitative research. Third edition. Sage Publications, Thousand Oaks, California, USA.

Galley, G., and J. Clifton. 2004. The motivational and demographic characteristics of research ecotourists: operation Wallacea volunteers in southeast Sulawesi, Indonesia. Journal of Ecotourism 3 (1):69-82.

Glaser, B., and A. Strauss. 1967. The discovery of grounded theory: strategies for qualitative research. Aldine, Chicago, Illinois, USA.

Gray, N. J., and L. M. Campbell. 2007. A decommodified experience? Exploring aesthetic, economic, and ethical values for volunteer ecotourism in Costa Rica. Journal of Sustainable Tourism 15(5):463-482.

Halpenny, E. A., and L. T. Caissie. 2003. Volunteering on nature conservation projects: volunteer experience, attitudes and values. Tourism Recreation Research 28(3)25-33.

Hurst, R. 2003. Semi-structured interviews and focus groups. Pages 117-132 in N. Clifford and G.
Valentine, editors.Key methods in geography. Sage Publications, London, UK.

Jamison, A. 1996. The shaping of the global environmental agenda: the role of nongovernmental organizations. Pages 224-245 in S. Lash, B. Szerszynski, and B. Wynne, editors. Risk, environment and modernity: towards a new ecology. Sage Publications, London, UK.

King, D., and W. Stewart. 1996. Ecotourism and commodification: protecting people and places. Biodiversity and Conservation 5(3):293-305.

Latour, B. 1993. We have never been modern. Harvester Wheatsheaf, London, UK.

Lorimer, J. 2007. Nonhuman charisma. Environment and Planning D 25(5):911-932.

Lorimer, J. 2009. The scope of international conservation volunteering from the UK. Oryx, in press.

Manning, P., and B. Cullum Swann. 1994. Narrative, content and semiotic analysis. Pages 463-477 in N. Denzin and Y. Lincoln, editors. Handbook of qualitative research. Sage Publications, London, UK.

Mansfield, B. 2007. Privatization: property and the remaking of nature-society relations introduction to the special issue. Antipode 39(3):393-405.

Marshall, C., and G. Rossman. 1995. Designing qualitative research. Second edition. Sage Publications, Thousand Oaks, California, USA.

McAffee, K. 1999. Selling nature to save it? Biodiversity and green developmentalism. Environment and Planning D 17:133-54.

McGehee, N. G. 2002. Alternative tourism and social movements. Annals of Tourism Research 29 (1):124-143.

McGehee, N. G., and W. C. Norman. 2002. Alternative tourism as impetus for consciousraising. Tourism Analysis 6:239-251.

Mumby, P. J., A. R. Harborne, P. S. Raines, and J. M. Ridley. 1995. A critical assessment of data derived from Coral Cay conservation volunteers. Bulletin of Marine Sciences 56(3):737-751. 
Parliamentary Office of Science and Technology (POST). 2000. Biodiversity and conservation. Her Majesty's Stationary Office, London, UK.

Rhodes, R. 1996. The new governance: governing without government. Political Studies XLIV:652667.

Russel, C. 1995. The social construction of orangutans: an ecotourist experience. Society and Animals 3(2): 151-169.

Secretariat of the Convention on Biological Diversity. 2001. Convention on biological diversity handbook. Earthscan, London, UK.

Stebbins, R. A., and M. M. Graham. 2004. Volunteering as leisure/leisure as volunteering. CAB International, Wallingford, Oxon, UK.

Thornes, J.E., and Randalls, S., 2007. Commodifying the atmosphere: "Pennies from heaven?" Geografiska Annaler 89A(4):1-13.

Turner, R., G. Miller, and D. Gilbert. 2001. The role of UK charities and the tourism industry. Tourism Management 22:463-472.

Urry, J. 1990. The tourist gaze. Sage Publications, London, UK.

Wearing, S. 2001. Volunteer tourism: experiences that make a difference. CAB International, Wallingford, Oxon, UK.

Weaver, D. 2001. Ecotourism. Wiley, Milton, Australia.

Weiler, B., and H. Richins. 1995. Extreme, extravagant and elite: a profile of ecotourists on Earthwatch expeditions. Tourism Recreation Research 20(1):29-36.

Weston, M., M. Fendley, R. Jewell, M. Satchell, and C. Tzaros. 2003. Volunteers in bird conservation: insights from the Australian Threatened Bird Network. Ecological Management and Restoration 4(3):205-211.

Whatmore, S. 2002. Hybrid geographies: natures, cultures, spaces. Sage Publications, London, UK.

Wheeller, B. 1993. Sustaining the ego. Journal of Sustainable Tourism 1(2):121-129.
Wilson, E. 1992. The diversity of life. Penguin, London, UK.

Year Out Group. 2008. Why choose YOG? [online] URL: http://www.yearoutgroup.org/. Accessed 12 March 2008. 